\title{
THE EFFECT OF ADDITION OF SELECTED MILK PROTEIN PREPARATIONS ON THE GROWTH OF LACTOBACILLUS ACIDOPHILUS AND PHYSICOCHEMICAL PROPERTIES OF FERMENTED MILK
}

\author{
Waldemar Gustaw ${ }^{1 凶}$, Justyna Kozioł ${ }^{1}$, Wojciech Radzki ${ }^{1}$, Katarzyna Skrzypczak ${ }^{1}$, \\ Monika Michalak-Majewska ${ }^{1}$, Bartosz Sołowiej ${ }^{2}$, Aneta Sławińska ${ }^{1}$, \\ Ewa Jabłońska-Ryśs
}

${ }^{1}$ Department of Fruits, Vegetables and Mushrooms Technology, University of Life Sciences in Lublin Skromna 8, 20-704 Lublin, Poland

${ }^{2}$ Department of Milk Technology and Hydrocolloids, University of Life Sciences in Lublin

Skromna 8, 20-704 Lublin, Poland

\begin{abstract}
Background. The intake of fermented milk products, especially yoghurts, has been systematically increasing for a few decades. The purpose of this work was to obtain milk products fermented with a mix of bacterial cultures (yoghurt bacteria and Lactobacillus acidophillus LA-5) and enriched with selected milk protein preparations. Secondly, the aim of the work was to determine physiochemical and rheological properties of the obtained products.

Material and methods. The following additives were applied in the experiment: whey protein concentrate (WPC 65), whey protein isolate (WPI), demineralised whey powder (SPD), caseinoglycomacropeptide (CGMP), $\alpha$-lactalbumin $(\alpha$-la), sodium caseinate $(\mathrm{KNa})$ and calcium caseinate $(\mathrm{KCa})$. Milk was fermented using probiotic strain Lactobacillus acidophillus LA-5 and a typical yoghurt culture. The products were analysed in terms of the survivability of bacterial cells during refrigerated storage, rheological properties and syneresis. Fermented milk products were obtained using blends of bacterial strains: ST-B01:Lb-12 (1:1), ST-B01:Lb-12:LA-5 (1:1:2).

Results. Milk beverages fermented with typical yoghurt bacteria and LA-5 strain showed intensive syneresis. The addition of LA-5 strain caused formation of harder acid gels, comparing to typical yoghurts. Milk products which were prepared from skimmed milk possessed higher values of hardness and consistency coefficient. The increase of concentrations of milk preparations (except of WPI) did not cause significant differences in the hardness of acidic gels obtained by fermentation of mixed culture with a probiotic strain. Conclusion. The applied preparations improved physiochemical properties of the milk beverages which were prepared with a probiotic strain. The increase of protein milk preparations concentration resulted in a gradual decrease of the secreted whey. Among the products that were made of full milk powder and were subjected to three weeks of refrigerated storage the highest survivability of Lb. acidophilus LA-5 was noticed in the samples fortified with $1 \%$ WPC.
\end{abstract}

Key words: milk protein preparations, rheology, syneresis, Lactobacillus acidophillus 


\section{INTRODUCTION}

In recent decades, the consumption of fermented beverages, especially yoghurts, has systematically increased (Tamime and Robinson, 2007). Yoghurt is a beverage which is traditionally produced using a mixture of thermophilic starter cultures consisting of Lactobacillus delbrueckii ssp. bulgaricus and Streptococcus thermophilus (Gustaw, 2008). Probiotic microorganisms grow slowly in milk and thus are frequently used with yoghurt starter cultures (Tamime and Robinson, 2007). Probiotic bacteria such as Lactobacillus acidophilus and Bifidobacterium spp. are also included due to their potential health benefits (Donkor et al., 2007). The Lactobacillus sp. genus is the most studied one and it has been widely used in probiotic foods in recent years. Probiotic bacteria must meet the following criteria: (1) survive storage and processing operations; (2) be able to survive in gastric environment which includes the resistance to hydrolytic enzymes and bile salts secreted in the gastrointestinal tract; (3) must not adversely affect the physicochemical and sensory characteristics of the product (Ding and Shah, 2007; Liu et al., 2007). Lactobacillus delbrueckii ssp. bulgaricus may decrease acidity of yoghurts during storage. As a consequence, it may lower the survivability of Lactobacillus acidophilus (Saccaro et al., 2009). In recent years, a considerable amount of research focused on determining which constituents enhance growth and viability of Lactobacillus genus in milk products (Castro et al., 2009; Gustaw et al., 2011; Kozioł et al., 2013; 2014; Matijević et al., 2008). Previous research investigated the influence of milk oligosaccharides or proteins on products in which bacterial monoculture was used. However, few studies verified if these compounds enhance growth and viability of probiotic bacteria in products made with the mixed cultures. The aim of the present study was to prepare fermented milk beverages enriched with selected milk proteins using yoghurt bacteria and Lactobacillus acidophillus LA-5. The other purpose was to assess physical and chemical properties of the prepared beverages and the effect of milk proteins on viability of the used probiotic strain.

\section{MATERIAL AND METHODS}

Three bacterial strains were used in the study: Lactobacillus acidophilus LA-5, Streptococcus salivarius ssp. thermophilus ST-B01, Lactobacillus delbrueckii ssp. bulgaricus (Chr. Hansen, Poland).

Milk products were prepared using: whole milk powder (PMP), (OSM Krasnystaw); skimmed milk powder (OMP), (Biomlek Chełm); whey protein concentrate (WPC 65; Milei GmbH, Allgau, Germany), whey protein isolate (WPI; Milei GmbH, Allgau, Germany); demineralised whey powder (SPD; Euroserum, Port-Sur-Saone, France), sodium and calcium caseinate (Polsero, Poland), caseinoglycomacropeptide (CGMP) and $\alpha$-lactalbumin ( $\alpha$-la; Arla Food, Denmark).

Preparing of fermented milk beverages. For inoculum preparations, sterile 10\% regenerated OMP was inoculated with $100 \mathrm{ml}$ of bacterial suspension (Lactobacillus acidophillus LA-5, Streptococcus thermophilus ST-B01, Lactobacillus delbrueckii ssp. bulgaricus $\mathrm{Lb} 12)$. It was then incubated at $37^{\circ} \mathrm{C}\left(\mathrm{ST}-\mathrm{B} 01\right.$ at $\left.42^{\circ} \mathrm{C}\right)$ until a concentration of $10^{7}-10^{8} \mathrm{cfu} / \mathrm{ml}$ was obtained (Donkor et al., 2007). The number of bacteria cells was quantified with a plate count method using M17 medium (BTL, Poland) for ST-B01 strain, MRS agar medium (BTL, Poland) at $\mathrm{pH} 5.4$ for Lb12 strain and MRS agar medium which contained lithium chloride $(0.2 \%)$ and sodium propionate $(0.3 \%)$ for LA-5 strain.

OMP and PMP 13\% solutions were made by stirring in distilled water using a MS 11HS (WIGO, Poland) magnetic stirrer. Milk protein preparations $(0.5 \%, 1 \%$ and $2 \%)$ were added to the regenerated milk. The obtained solutions were pasteurized at $80^{\circ} \mathrm{C}$ for $30 \mathrm{~min}$ in a MLL 147 water bath (AJL Electronic, Poland). Then the mixtures were cooled to room temperature and the inoculum were added at the concentration of $2 \%$. Fermented milk products were prepared using blends of bacterial cultures: ST-B01:Lb-12 (1:1) or ST-B01:Lb-12:LA-5 (1:1:2).

Determination of syneresis in fermented milk beverages. Syneresis was determined $12 \mathrm{~h}$ after fermentation process stopped according to the methodology described by Kozioł et al. (2014).

The effect of milk proteins preparations on cell survivability of Lactobacillus acidophillus LA-5 during refrigerated storage. Living cells of Lactobacillus acidophillus LA-5 were quantified with plate 
count method using MRS agar medium which contained lithium chloride $(0.2 \%)$ and sodium propionate $(0.3 \%)$. Bacteria were enumerated at 1 st, 7 th, 14 th, and 21 st day of refrigerated storage. The quantifications of bacteria were done in duplicate.

Rheological and textural properties of fermented milk products. Hardness was determined with TA-XT2i texture analyzer (Stable Micro Systems, Godalming. UK) after $12 \mathrm{~h}$ of refrigerated storage at $4^{\circ} \mathrm{C}$. The samples were analysed with modified TPA test (Kozioł et al., 2013; 2014). The probe diameter was $15 \mathrm{~mm}$, the distance of penetration $20 \mathrm{~mm}$ and the speed of the probe was fixed at $1 \mathrm{~mm} / \mathrm{s}$. The measurements were done in two series and each series comprised of five repetitions.

Flow curves were established at the shear rate of $0-150 \mathrm{1} / \mathrm{s}$, at $20^{\circ} \mathrm{C}$ for $120 \mathrm{~s}$. The measurements were done using a con-plate measuring system $\left(\mathrm{C} 60 / 2^{\circ} \mathrm{Ti}\right)$ and a dynamic rheometer RS 300 (Haake, Karlsruhe, Germany). The established flow curves were analysed with a Herschel-Bulkey model (RheoWin 3, Haake, Karlsruhe, Germany).

Mechanical spectra of the milk beverages were recorded at the frequency of $0.1-10 \mathrm{~Hz}$ at the strain of 0.01 . The measurements were done at $20^{\circ} \mathrm{C}$ using a cone-plate measuring system $\left(\mathrm{C} 60 / 2^{\circ} \mathrm{Ti}\right)$ and a dynamic rheometer RS 300 (Haake, Karlsruhe, Germany).

Fermentation of milk beverages was determined with dynamic rheometer RS 300 (Haake, Karlsruhe, Germany). Changes of storage and loss modulus (G' and G') were recorded at $f=0.1 \mathrm{~Hz}$ and strain 0.01 . The gel point of whey protein was measured as the point when G' equalled G", i.e. $\delta=45^{\circ}$.

Statistical analysis. Statistical analysis was performed with Statistica 8.0 (StatSoft. Polska). The data were evaluated using analysis of variance (ANOVA) with a level of significance set at $P \leq 0.05$. Tukey's test was carried out to compare the data.

\section{RESULTS AND DISCUSSION}

Table 1 presents the results on hardness of fermented milk beverages depending on fat content and the concentration of the added protein preparations. Fermented milk which was prepared from OMP possessed higher hardness comparing to the milk prepared from PMP. The addition of WPI to OMP at the concentration of $0.5 \%$ caused the improvement of acid gel texture. However, the addition of other preparations did not influence the hardness or even worsened the textural properties. Among the milk products made from PMP, the hardest acid gels $(1.44 \mathrm{~N})$ were obtained when WPI was added at the concentration of $2 \%$. The lowest values $(0.20 \mathrm{~N})$ were observed for the PMP samples where WPC65 was applied at the concentration of $2 \%$.

Determining the level of syneresis of the fermented milk beverages allowed to evaluate the influence of the used milk protein preparations and bacterial strains on consistence and stability of casein gels. Adding LA-5 strain to a typical yoghurt culture caused formation of acid gels which released large quantity of whey, comparing to typical yoghurts made of both OMP and PMP (Table 2). The highest amount of whey (9.11\%) was observed in the products made of PMP supplemented with $0.5 \% \mathrm{KCa}$. Relatively high syneresis was noticed in the case of milk beverages which were fermented with WPC65 and SPD. To the contrary, the samples prepared from PMP and OMP, both supplemented with $2 \% \mathrm{WPI}$, possessed the lowest syneresis. The level of syneresis in the beverages made with the mixed culture (ST-B01, Lb-12 and LA-5) decreased along with higher content of the added protein supplements. The results are consistent with previous research in which the effect of adding milk preparations on syneresis of fermented milk beverages (Kozioł et al., 2014; Kuecuekcetin, 2008). The lower syneresis which occurred after adding higher amounts of milk proteins can be explained by the denser crosslinking of the acid gels comparing to control samples (Puvanenthiran et al., 2002).

The obtained fermented milk beverages were further analysed in terms of their rheological properties. The beverages prepared with OMP and fortified with $1 \%$ CGMP possessed different flow curves, depending on the used bacterial mono culture. However, the shape of the curves of the all analysed products showed pseudoplastic properties (Fig. 1).

The addition of probiotic strain (LA-5) to a typical yoghurt culture caused formation of stronger acid gels, comparing to milk which was fermented solely with a typical yoghurt culture.

The enrichment of a typical yoghurt culture with the prebiotic strain LA-5 and using it to ferment 
Gustaw, W., Kozioł, J., Radzki, W., Skrzypczak, K., Michalak-Majewska, M., Sołowiej, B., Sławińska, A., Jabłońska-Ryś, E. (2016). The effect of addition of selected milk protein preparations on the growth of Lactobacillus acidophilus and physicochemical properties of fermented milk. Acta Sci. Pol. Technol. Aliment., 15(1), 29-36. DOI: 10.17306/J.AFS.2016.1.3

Table 1. Hardness [N] of fermented milk products by typical yoghurt cultures ST-B01 (S. thermophilus) and Lb-12 (L. bulgaricus) with the addition of LA-5 (L. acidophilus)

\begin{tabular}{|c|c|c|c|c|c|c|c|c|}
\hline \multirow{2}{*}{$\begin{array}{c}\text { Concentration } \\
\text { of preparations } \\
\%\end{array}$} & \multicolumn{8}{|c|}{ Milk protein preparations } \\
\hline & OMP & CGMP & $\alpha-1 \mathrm{a}$ & WPC65 & SPD & WPI & $\mathrm{KNa}$ & $\mathrm{KCa}$ \\
\hline 0 & $\begin{aligned} & 0.56^{\text {efg }} \\
\pm & 0.04\end{aligned}$ & & & & & & & \\
\hline 0.5 & & $\begin{array}{l}0.53^{\operatorname{defg}} \\
\pm 0.06\end{array}$ & $\begin{array}{l}0.61^{\mathrm{fg}} \\
\pm 0.06\end{array}$ & $\begin{array}{l}0.49^{\text {def }} \\
\pm 0.03\end{array}$ & $\begin{array}{l}0.46^{\text {cdef }} \\
\pm 0.04\end{array}$ & $\begin{array}{l}0.79^{\text {hi }} \\
\pm 0.07\end{array}$ & $\begin{array}{l}0.43^{\text {cde }} \\
\pm 0.02\end{array}$ & $\begin{array}{l}0.40^{\text {bcd }} \\
\pm 0.02\end{array}$ \\
\hline 1 & & $\begin{aligned} & 0.56^{\mathrm{efg}} \\
\pm & 0.05\end{aligned}$ & $\begin{array}{c}0.78^{\mathrm{hi}} \\
\pm 0.02\end{array}$ & $\begin{array}{l}0.49^{\text {def }} \\
\pm 0.04\end{array}$ & $\begin{aligned} & 0.55^{\text {defg }} \\
\pm & 0.05\end{aligned}$ & $\begin{array}{r}1.03^{\mathrm{i}} \\
\pm 0.06\end{array}$ & 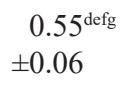 & $\begin{array}{l}0.54^{\text {defg }} \\
\pm 0.03\end{array}$ \\
\hline 2 & & $\begin{aligned} & 0.31^{\mathrm{abc}} \\
\pm & 0.05\end{aligned}$ & $\begin{array}{l}0.60^{\mathrm{fg}} \\
\pm 0.06\end{array}$ & $\begin{array}{c}0.23^{\mathrm{a}} \\
\pm 0.04\end{array}$ & $\begin{aligned} & 0.26^{\mathrm{ab}} \\
\pm & 0.05\end{aligned}$ & $\begin{aligned} & 1.37^{\mathrm{j}} \\
\pm & 0.09\end{aligned}$ & $\begin{array}{r} \\
0.87^{\mathrm{i}} \\
\pm 0.05\end{array}$ & $\begin{array}{l}0.68^{\mathrm{gh}} \\
\pm 0.03\end{array}$ \\
\hline 0 & $\begin{array}{c}\text { PMP } \\
0.42^{\text {cdef }} \\
\pm 0.06\end{array}$ & & & & & & & \\
\hline 0.5 & & $\begin{aligned} & 0.35^{\text {abcde }} \\
\pm & 0.01\end{aligned}$ & $\begin{array}{l}0.46^{\text {def }} \\
\pm 0.02\end{array}$ & $\begin{aligned} & 0.36^{\text {abcde }} \\
\pm & 0.03\end{aligned}$ & $\begin{array}{l} \\
0.38^{\text {bcde }} \\
\pm 0.03\end{array}$ & $\begin{array}{l}0.56^{\mathrm{fgh}} \\
\pm 0.06\end{array}$ & 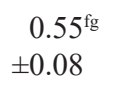 & 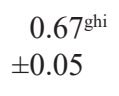 \\
\hline 1 & & $\begin{aligned} & 0.34^{\mathrm{abcd}} \\
\pm & 0.03\end{aligned}$ & $\begin{array}{l}0.51^{\text {efg }} \\
\pm 0.02\end{array}$ & $\begin{array}{l}0.28^{\mathrm{abc}} \\
\pm 0.02\end{array}$ & 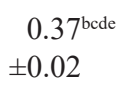 & $\begin{aligned} & 0.72^{\text {hi }} \\
\pm & 0.05\end{aligned}$ & $\begin{aligned} & 0.57^{\mathrm{fgh}} \\
\pm & 0.04\end{aligned}$ & $\begin{array}{c}0.81^{\mathrm{ij}} \\
\pm 0.02\end{array}$ \\
\hline 2 & & 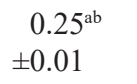 & $\begin{array}{l}0.45^{\text {def }} \\
\pm 0.07\end{array}$ & $\begin{array}{c}0.20^{\mathrm{a}} \\
\pm 0.04\end{array}$ & $\begin{array}{l}0.30^{\text {abcd }} \\
0.03\end{array}$ & $\begin{aligned} & 1.44^{\mathrm{k}} \\
& \pm 0.10\end{aligned}$ & $\begin{array}{r}0.89^{\mathrm{j}} \\
\pm 0.08\end{array}$ & $\begin{array}{r}0.92^{\mathrm{j}} \\
\pm 0.11\end{array}$ \\
\hline
\end{tabular}

Table shows mean values \pm standard deviations; $n=5$, differences amid means obtained from one type of milk, denoted by different letters are statistically significant $(p<0.05)$.

regenerated OMP and PMP fortified with milk protein preparations caused minor increase of consistency coefficient $(K)$. This effect was not noticed in case of yoghurts made with a typical yoghurt culture (Table 3). However the fortified samples made from OMP with addition of milk preparations had usually higher $K$ values comparing to the samples made from PMP. When both kinds of regenerated milk were supplemented with $\mathrm{KNa}, \mathrm{KCa}$ and WPI, the higher $K$ values were noticed. Blending of LA-5 strain with a typical yoghurt culture did not cause relevant changes of flow index $(n)$.

Table 4 shows gel point of whole milk fermented with bacterial monocultures (ST-B01 or LA-5) or their blend. Additionally it presents G' and G' values obtained after the samples were cooled down to $5^{\circ} \mathrm{C}$. Regardless of the strain used the samples containing $1 \%$ of CGMP or $1 \alpha$-la formed gels quicker compare to the beverages prepared form PMP (control). The time needed for the formation of acid gel depended on the applied culture. Fermenting of whole milk with monocultures lasted longer than the mixed cultures.

Milk beverages fermented with LA- 5 strain showed the longest time $(617-647 \mathrm{~min})$ to form a gel structure (Table 4). The enrichment of yoghurt culture with a LA-5 strain significantly quickened fermentation (183-194 min). The values of storage modulus and loss modulus depended on the type of applied protein preparation. The lowest G' and G" values were displayed by the samples which were enriched with $1 \% \alpha$-la.

Population of LA-5 strain which was used to enrich typical yoghurt culture was lower in the produced beverages when compared to the samples prepared with LA-5 monoculture (Table 5). After 1 day of refrigerated storage the number of bacterial cells in the control samples made of PMP, the samples with $1 \%$ CGMP or WPC65, achieved $10^{7} \mathrm{CFU} / \mathrm{ml}$. 
Gustaw, W., Kozioł, J., Radzki, W., Skrzypczak, K., Michalak-Majewska, M., Sołowiej, B., Sławińska, A., Jabłońska-Ryś, E. (2016). The effect of addition of selected milk protein preparations on the growth of Lactobacillus acidophilus and physicochemical properties of fermented milk. Acta Sci. Pol. Technol. Aliment., 15(1), 29-36. DOI: 10.17306/J.AFS.2016.1.3

Table 2. Syneresis volume of fermented milk beverages with the added milk protein preparations, produced through the fermentation by ST-B01 (S. thermophilus), Lb-12 (L. bulgaricus) and LA-5 (L. acidophilus) strains

\begin{tabular}{|c|c|c|c|c|c|c|c|c|}
\hline \multirow{2}{*}{$\begin{array}{c}\text { Concentration of } \\
\text { preparations } \\
\%\end{array}$} & \multicolumn{8}{|c|}{ Milk protein preparations } \\
\hline & OMP & CGMP & $\alpha-l a$ & WPC65 & SPD & WPI & $\mathrm{KNa}$ & $\mathrm{KCa}$ \\
\hline 0 & $\begin{array}{l}5.11^{\mathrm{hi}} \\
\pm 0.11\end{array}$ & & & & & & & \\
\hline 0.5 & & $\begin{array}{r}8.96^{\mathrm{k}} \\
\pm 0.36\end{array}$ & $\begin{array}{c}3.80^{\mathrm{ef}} \\
\pm 0.07\end{array}$ & $\begin{array}{c}3.62^{\mathrm{e}} \\
\pm 0.10\end{array}$ & $\begin{array}{r}7.75^{\mathrm{j}} \\
\pm 0.18\end{array}$ & $\begin{array}{l}2.87^{\mathrm{cd}} \\
\pm 0.32\end{array}$ & $\begin{array}{l}4.75^{\mathrm{gh}} \\
\pm 0.27\end{array}$ & $\begin{array}{r}5.45^{\mathrm{i}} \\
\pm 0.33\end{array}$ \\
\hline 1 & & 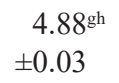 & $\begin{aligned} & 2.65^{c} \\
\pm & 0.07\end{aligned}$ & $\begin{array}{l}2.92^{\text {cd }} \\
\pm 0.09\end{array}$ & $\begin{aligned} & 4.35^{\mathrm{fg}} \\
\pm & 0.17\end{aligned}$ & $\begin{aligned} & 1.04^{\mathrm{ab}} \\
& \pm 0.04\end{aligned}$ & $\begin{array}{l}2.90^{\text {cd }} \\
\pm 0.12\end{array}$ & $\begin{aligned} & 5.10^{\mathrm{hi}} \\
\pm & 0.25\end{aligned}$ \\
\hline 2 & & $\begin{array}{r}3.69^{\mathrm{e}} \\
\pm 0.15\end{array}$ & $\begin{array}{c}1.21^{\mathrm{b}} \\
\pm 0.13\end{array}$ & $\begin{array}{c}2.37^{c} \\
\pm 0.08\end{array}$ & $\begin{array}{l}3.40^{\text {de }} \\
\pm 0.12\end{array}$ & 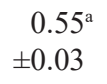 & $\begin{array}{l}2.87^{\mathrm{cd}} \\
\pm 0.11\end{array}$ & $\begin{aligned} & 2.90^{\text {cd }} \\
& \pm 0.19\end{aligned}$ \\
\hline & PMP & & & & & & & \\
\hline 0 & $\begin{array}{c}5.84^{\mathrm{f}} \\
\pm 0.10\end{array}$ & & & & & & & \\
\hline 0.5 & & $\begin{array}{c} \\
\quad 6.66^{\mathrm{hi}} \\
\pm 0.04\end{array}$ & $\begin{aligned} & 4.07^{\mathrm{d}} \\
\pm & 0.05\end{aligned}$ & $\begin{array}{r}7.24 \mathrm{j} \\
\pm 0.43\end{array}$ & $\begin{array}{r}7.36^{\mathrm{j}} \\
\pm 0.11\end{array}$ & $\begin{array}{r}2.98^{\mathrm{c}} \\
\pm 0.05\end{array}$ & $\begin{array}{l}\quad 6.93^{\text {hi }} \\
\pm 0.34\end{array}$ & $\begin{array}{r}9.11^{\mathrm{k}} \\
\pm 0.27\end{array}$ \\
\hline 1 & & $\begin{aligned} & 5.14^{\mathrm{e}} \\
& \pm 0.23\end{aligned}$ & $\begin{array}{r}2.74^{\mathrm{c}} \\
\pm 0.04\end{array}$ & $\begin{array}{c}4.17^{\mathrm{d}} \\
\pm 0.09\end{array}$ & $\begin{array}{l}7.10^{\mathrm{ij}} \\
\pm 0.14\end{array}$ & 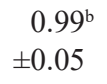 & $\begin{aligned} & 5.06^{\mathrm{e}} \\
& \pm 0.18\end{aligned}$ & $\begin{aligned} & 5.98^{\mathrm{fg}} \\
\pm & 0.21\end{aligned}$ \\
\hline 2 & & $\begin{array}{c}2.49^{\mathrm{c}} \\
\pm 0.08\end{array}$ & $\begin{array}{c}0.80^{\mathrm{ab}} \\
\pm 0.12\end{array}$ & $\begin{array}{c}2.78^{\mathrm{c}} \\
\pm 0.04\end{array}$ & $\begin{aligned} & 6.36^{\mathrm{gh}} \\
\pm & 0.10\end{aligned}$ & $\begin{array}{c}0.36^{\mathrm{a}} \\
\pm 0.02\end{array}$ & 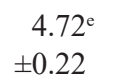 & $\begin{array}{r}5.20^{\mathrm{e}} \\
\pm 0.17\end{array}$ \\
\hline
\end{tabular}

Table shows mean values \pm standard deviations; $n=5$, differences amid means obtained from one type of milk, denoted by different letters are statistically significant $(p<0.05)$.

A

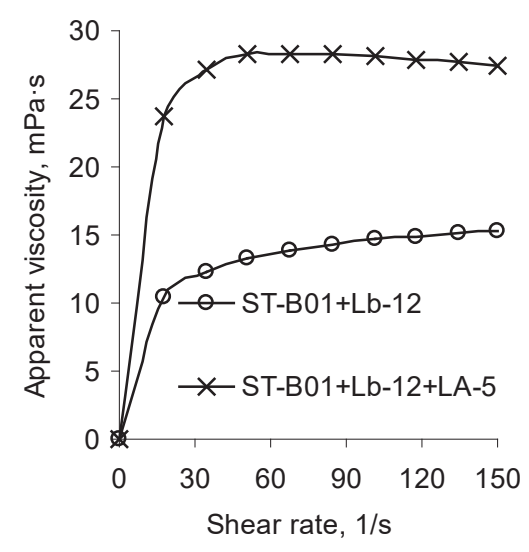

B

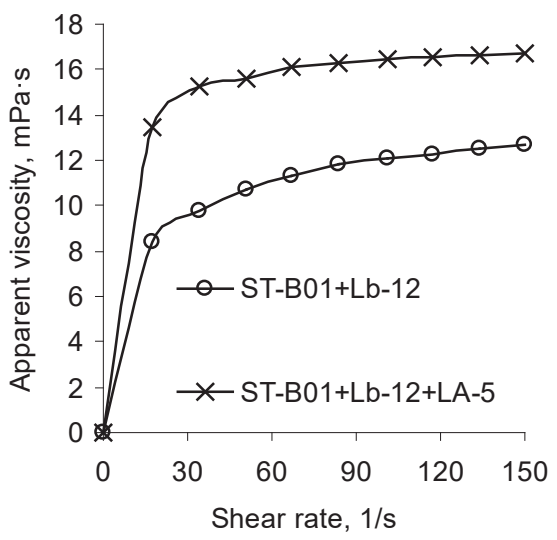

Fig. 1. Flow curves of the fermented milk products obtained with the addition of $1 \%$ CGMP: A - OMP, B - PMP 
Gustaw, W., Kozioł, J., Radzki, W., Skrzypczak, K., Michalak-Majewska, M., Sołowiej, B., Sławińska, A., Jabłońska-Ryś, E. (2016). The effect of addition of selected milk protein preparations on the growth of Lactobacillus acidophilus and physicochemical properties of fermented milk. Acta Sci. Pol. Technol. Aliment., 15(1), 29-36. DOI: 10.17306/J.AFS.2016.1.3

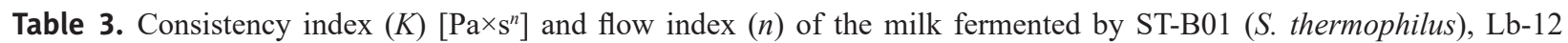
(L. bulgaricus) and LA-5 (L. acidophilus) strains with the addition of different milk protein preparations

\begin{tabular}{|c|c|c|c|c|c|c|c|c|c|}
\hline \multirow{2}{*}{$\begin{array}{c}\text { Concentration } \\
\text { preparation } \\
\%\end{array}$} & \multirow{2}{*}{$\begin{array}{l}\text { Rheological } \\
\text { parameters }\end{array}$} & \multicolumn{8}{|c|}{ Milk protein preparations } \\
\hline & & OMP & CGMP & $\alpha-1 a$ & WPC65 & $\mathrm{KCa}$ & $\mathrm{KNa}$ & SPD & WPI \\
\hline \multirow[t]{2}{*}{0} & $K$ & $\begin{array}{l}546.9^{\text {efg }} \\
\pm 67.4\end{array}$ & & & & & & & \\
\hline & $n$ & $\begin{array}{r}0.10 \\
\pm 0.01\end{array}$ & & & & & & & \\
\hline \multirow[t]{2}{*}{0.5} & $K$ & & $\begin{array}{l}420.8^{\mathrm{cd}} \\
\pm 37.3\end{array}$ & $\begin{array}{l}471.4^{\text {cdef }} \\
\pm 18.6\end{array}$ & $\begin{array}{l}506.4^{\text {defg }} \\
\pm 36.1\end{array}$ & $\begin{array}{l}845.4^{\mathrm{h}} \\
\pm 11.8\end{array}$ & $\begin{array}{l}815.8^{\mathrm{h}} \\
\pm 20.2\end{array}$ & $\begin{array}{l}392.2^{\mathrm{bc}} \\
\pm 46.8\end{array}$ & $\begin{array}{l}444.5^{\text {cde }} \\
\pm 21.1\end{array}$ \\
\hline & $n$ & & $\begin{array}{r}0.10 \\
\pm 0.01\end{array}$ & $\begin{array}{r}0.10 \\
\pm 0.02\end{array}$ & $\begin{array}{r}0.10 \\
\pm 0.02\end{array}$ & $\begin{array}{r}0.09 \\
\pm 0.01\end{array}$ & $\begin{array}{r}0.09 \\
\pm 0.00\end{array}$ & $\begin{array}{r}0.11 \\
\pm 0.03\end{array}$ & $\begin{array}{r}0.10 \\
\pm 0.01\end{array}$ \\
\hline \multirow[t]{2}{*}{1} & $K$ & & $\begin{array}{l}492.1^{\text {cdefg }} \\
\pm 26.2^{2}\end{array}$ & $\begin{array}{l}593.5^{\mathrm{g}} \\
\pm 12.9^{2}\end{array}$ & $\begin{array}{l}560.9^{\mathrm{fg}} \\
\pm 27.4\end{array}$ & $\begin{array}{r}1035.0^{\mathrm{i}} \\
\pm 40.1\end{array}$ & $\begin{array}{c}1123.0^{\mathrm{ij}} \\
\pm 29.1\end{array}$ & $\begin{array}{l}518.6^{\text {defg }} \\
\pm 39.0\end{array}$ & $\begin{array}{l}769.1^{\mathrm{h}} \\
\pm 49.5\end{array}$ \\
\hline & $n$ & & $\begin{array}{r}0.10 \\
\pm 0.01\end{array}$ & $\begin{array}{r}0.10 \\
\pm 0.02\end{array}$ & $\begin{array}{r}0.10 \\
\pm 0.01\end{array}$ & $\begin{array}{r}0.09 \\
\pm 0.00\end{array}$ & $\begin{array}{r}0.09 \\
\pm 0.01\end{array}$ & $\begin{array}{r}0.10 \\
\pm 0.02\end{array}$ & $\begin{array}{r}0.09 \\
\pm 0.01\end{array}$ \\
\hline \multirow[t]{3}{*}{2} & K & & $\begin{array}{l}227.6^{\mathrm{a}} \\
\pm 21.2\end{array}$ & $\begin{array}{l}308.5^{\mathrm{ab}} \\
\pm 34.2\end{array}$ & $\begin{array}{l}239.3^{\mathrm{a}} \\
\pm 19.6\end{array}$ & $\begin{array}{c}1288.0^{\mathrm{k}} \\
\pm 41.1\end{array}$ & $\begin{array}{c}1528.0^{1} \\
\pm 39.8\end{array}$ & $\begin{array}{l}198.7^{\mathrm{a}} \\
\pm 37.1\end{array}$ & $\begin{array}{c}1146.0^{\mathrm{j}} \\
\pm 46.0\end{array}$ \\
\hline & $n$ & & $\begin{array}{r}0.12 \\
\pm 0.02\end{array}$ & $\begin{array}{r}0.10 \\
\pm 0.03\end{array}$ & $\begin{array}{r}0.11 \\
\pm 0.02\end{array}$ & $\begin{array}{r}0.09 \\
\pm 0.01\end{array}$ & $\begin{array}{r}0.09 \\
\pm 0.00\end{array}$ & $\begin{array}{r}0.14 \\
\pm 0.03\end{array}$ & $\begin{array}{r}0.09 \\
\pm 0.00\end{array}$ \\
\hline & & PMP & & & & & & & \\
\hline \multirow[t]{2}{*}{0} & K & $\begin{array}{l}355.9^{\mathrm{g}} \\
\pm 16.1\end{array}$ & & & & & & & \\
\hline & $n$ & $\begin{array}{r}0.11 \\
\pm 0.01\end{array}$ & & & & & & & \\
\hline \multirow[t]{2}{*}{0.5} & $K$ & & $\begin{array}{l}226.5^{\text {bcd }} \\
\pm 32.2\end{array}$ & $\begin{array}{l}295.4^{\text {defg }} \\
\pm 42.5\end{array}$ & $\begin{array}{l}258.9^{\text {cdef }} \\
\pm 37.6\end{array}$ & $\begin{array}{l}466.4^{\mathrm{h}} \\
\pm 28.8\end{array}$ & $\begin{array}{l}554.0^{\mathrm{i}} \\
\pm 22.1\end{array}$ & $\begin{array}{l}245.1^{\text {cde }} \\
\pm 28.8\end{array}$ & $\begin{array}{l}345.2^{\mathrm{fg}} \\
\pm 27.7\end{array}$ \\
\hline & $n$ & & $\begin{array}{r}0.11 \\
\pm 0.02\end{array}$ & $\begin{array}{r}0.10 \\
\pm 0.01\end{array}$ & $\begin{array}{r}0.10 \\
\pm 0.02\end{array}$ & $\begin{array}{r}0.10 \\
\pm 0.02\end{array}$ & $\begin{array}{r}0.10 \\
\pm 0.01\end{array}$ & $\begin{array}{r}0.11 \\
\pm 0.02\end{array}$ & $\begin{array}{r}0.12 \\
\pm 0.04\end{array}$ \\
\hline \multirow[t]{2}{*}{1} & $K$ & & $\begin{array}{l}177.7^{\mathrm{abc}} \\
\pm 24.8\end{array}$ & $\begin{array}{l}341.1^{\mathrm{fg}} \\
\pm 36.3\end{array}$ & $\begin{array}{l}155.2^{\mathrm{ab}} \\
\pm 15.3\end{array}$ & $\begin{array}{l}748.2^{\mathrm{j}} \\
\pm 17.5^{2}\end{array}$ & $\begin{array}{l}859.7^{\mathrm{k}} \\
\pm 23.7\end{array}$ & $\begin{array}{l}245.0^{\text {cde }} \\
\pm 25.2\end{array}$ & $\begin{array}{l}704.7^{j} \\
\pm 32.4\end{array}$ \\
\hline & $n$ & & $\begin{array}{r}0.14 \\
\pm 0.03\end{array}$ & $\begin{array}{r}0.11 \\
\pm 0.01\end{array}$ & $\begin{array}{r}0.13 \\
\pm 0.02\end{array}$ & $\begin{array}{r}0.10 \\
\pm 0.01\end{array}$ & $\begin{array}{r}0.10 \\
\pm 0.00\end{array}$ & $\begin{array}{r}0.11 \\
\pm 0.01\end{array}$ & $\begin{array}{r}0.09 \\
\pm 0.00\end{array}$ \\
\hline \multirow[t]{2}{*}{2} & $K$ & & $\begin{array}{c}201.9^{\mathrm{abc}} \\
\pm 3.5\end{array}$ & $\begin{array}{c}329.4^{\mathrm{efg}} \\
\pm 8.1\end{array}$ & $\begin{array}{l}118.2^{\mathrm{a}} \\
\pm 11.9\end{array}$ & $\begin{array}{r}1372.0^{1} \\
\pm 2.8\end{array}$ & $\begin{array}{r}1330.0^{1} \\
\pm 6.8\end{array}$ & $\begin{array}{l}188.4^{\mathrm{abc}} \\
\pm 13.1\end{array}$ & $\begin{array}{l}948.9^{1} \\
\pm 65.2\end{array}$ \\
\hline & $n$ & & $\begin{array}{r}0.13 \\
\pm 0.02\end{array}$ & $\begin{array}{r}0.11 \\
\pm 0.01\end{array}$ & $\begin{array}{r}0.15 \\
\pm 0.01\end{array}$ & $\begin{array}{r}0.09 \\
\pm 0.00\end{array}$ & $\begin{array}{r}0.09 \\
\pm 0.01\end{array}$ & $\begin{array}{r}0.12 \\
\pm 0.02\end{array}$ & $\begin{array}{r}0.09 \\
\pm 0.03\end{array}$ \\
\hline
\end{tabular}

Table shows mean values \pm standard deviations; $n=3$, differences amid means obtained from one type of milk, denoted by different letters are statistically significant $(p<0.05)$. 

of fermented milk. Acta Sci. Pol. Technol. Aliment., 15(1), 29-36. DOI: 10.17306/J.AFS.2016.1.3

Table 4. Gel point (min), storage (G') and loss (G') modulus values [Pa] of the fermented milk obtained from PMP with the addition of different milk preparations

\begin{tabular}{llcll}
\hline \multicolumn{1}{c}{ Bacterial strain } & Milk preparations & Gel point, min & G', Pa & G', Pa \\
\hline ST-B01 & control sample & $220 \pm 2$ & $616 \pm 34$ & $143 \pm 16$ \\
& $1 \%$ CGMP & $209 \pm 1$ & $573 \pm 25$ & $134 \pm 8$ \\
& $1 \% \alpha$-la & $208 \pm 4$ & $924 \pm 39$ & $217 \pm 11$ \\
LA-5 & control sample & $647 \pm 5$ & $627 \pm 21$ & $150 \pm 5$ \\
& 1\% CGMP & $622 \pm 3$ & $660 \pm 32$ & $217 \pm 9$ \\
1\% $\alpha$-la & $617 \pm 2$ & $963 \pm 18$ & $251 \pm 19$ \\
control sample & $186 \pm 1$ & $570 \pm 22$ & $138 \pm 13$ \\
& $1 \%$ CGMP & $157 \pm 0$ & $674 \pm 19$ & $162 \pm 6$ \\
1\% $\alpha$-la & $176 \pm 1$ & $925 \pm 32$ & $227 \pm 12$ \\
& control sample & $194 \pm 3$ & $634 \pm 17$ & $132 \pm 11$ \\
& $1 \%$ CGMP & $187 \pm 3$ & $586 \pm 29$ & $123 \pm 15$ \\
& $1 \% \alpha$-la & $183 \pm 2$ & $887 \pm 26$ & $278 \pm 17$ \\
\hline
\end{tabular}

Yoghurts which were enriched with LA-5 strain and without addition of protein preparations showed reduced population $\left(10^{5} \mathrm{CFU} / \mathrm{ml}\right)$ after 14 days storage at $5^{\circ} \mathrm{C}$. The population was stable until the end of the storage period. The same results were noticed in the case of the samples which contained 1\% CGMP. To the contrary, the addition of 1\% WP65 enhanced survivability of LA- 5 cells in the samples. Its population after 21 days of refrigerated storage reached $8.61 \times 10^{6}$ $\mathrm{CFU} / \mathrm{ml}$. This number of cells of a prebiotic strain LA-5 in stored yoghurt guarantees beneficial effect on organisms who regularly consume it. Moreover, WPC 65 is the cheapest additive among the applied preparations. Therefore, its use will not cause an increase in the price of the products. Good survivability of Lactobacillus cells during refrigerated storage was observed by Kailasapathy and Supriadi (1996) who added WPC to yoghurts. Similar results were obtained in previous studies which scrutinized the influence of adding milk proteins preparations on survivability of monocultures of Lactobacillus genus (Gustaw et al., 2015; Kozioł et al., 2014). Lower survivability of bacterial cells, as the result of adding CGMP, was confirmed by Cicvárek et al. (2010) who used this kind of preparation to improve survivability of lactic acid bacteria.

Table 5. Survivability of LA-5 strain (L.acidophilus) in the milk fermented by the blend of bacterial cultures (ST-B01, Lb-12 and LA-5) with some milk proteins preparations during refrigerated storage

\begin{tabular}{cccc}
\hline \multirow{2}{*}{$\begin{array}{c}\text { Storage time } \\
\text { days }\end{array}$} & PMP & PMP $+1 \%$ CGMP & PMP + 1\% WPC65 \\
\cline { 2 - 4 } 1 & $2.68 \times 10^{7}$ & $2.06 \times 10^{7}$ & $2.71 \times 10^{7}$ \\
7 & $6.61 \times 10^{6}$ & $6.82 \times 10^{6}$ & $1.24 \times 10^{7}$ \\
14 & $8.52 \times 10^{5}$ & $7.73 \times 10^{5}$ & $9.07 \times 10^{6}$ \\
21 & $6.43 \times 10^{5}$ & $6.25 \times 10^{5}$ & $8.61 \times 10^{6}$ \\
\hline
\end{tabular}




\section{CONCLUSIONS}

The addition of whey protein preparations had a positive impact on rheological properties of fermented milk products. Milk beverages which were produced from skimmed milk showed higher values of hardness and consistency index. The increase of whey protein concentration usually has not caused significant differences in the hardness of acid gels which were prepared using the blend of bacterial cultures containing LA-5 probiotic strain. However, the exception was the addition of WPI. Milk beverages which were obtained with the use of mixed cultures showed high syneresis, regardless of the fat content in milk. The increase of whey protein preparations resulted in a gradual decrease of secreted whey. Among the products made of whole milk powder and subjected to three weeks of refrigerated storage the highest survivability of $L b$. acidophilus LA-5 was noticed in the samples fortified with $1 \%$ WPC. The addition of whey protein preparations can change sensory properties of milk products, therefore further research will involve sensory evaluation of prepared products.

\section{REFERENCES}

Cicvárek, J., Čurda, L., Elich, O., Dvorakova, E., Dvorak, M. (2010). Effect of caseinomacropeptide concentrate addition on the growth of bifidobacteria. Czech J. Food Sci., 28(6), 485-494.

Castro de, F. P., Cunha, T. M., Ogliari, P. J. F., Teofilo, R. F., Ferreira, M. M. C., Prudencio, E. S. (2009). Influence of different content of cheese whey and oligofructose on the properties of fermented lactic beverages: Study using response surface methodology. Food Sci. Technol., 42, 993-997.

Ding, W. K., Shah, N. P. (2007). Acid, bile, and heat tolerance of free and microencapsulated probiotic bacteria. J. Food Sci., 72, 446-450.

Donkor, O. N., Nilmini, S., Stolic, P., Vasiljevic, T., Shah, N. (2007). Survival and activity of selected probiotic lactic acid bacteria and probiotic organisms in set-type yoghurt during cold storage. Int. Dairy J., 17, 657-665.

Gustaw, W., Kordowska-Wiater, M., Kozioł, J. (2011). The influence of selected prebiotics on the growth of lactic acid bacteria for bio-yoghurt production. Acta Sci. Pol. Techn. Aliment., 10(4), 455-466.

Gustaw, W., Kozioł, J., Waśko, A., Skrzypczak, K., Michalak-Majewska, M., Nastaj, M. (2015). Właściwości fizykochemiczne i przeżywalność Lactobacillus casei w mlecznych napojach fermentowanych otrzymanych $\mathrm{z}$ dodatkiem wybranych preparatów białek mleka [Physicochemical properties and survival of Lactobacillus casei in fermented milk beverages produced with addition of selected milk protein preparations]. Żywn. Nauka Techn. Jakość 6(103), 129-139 [in Polish].

Gustaw, W. (2008). The effect of an oat-beta-glucan addition on the physico-chemical properties of a set yoghurt. Milchwissenschaft, 63(3), 296-298.

Kailasapathy, K., Supriadi, D. (1996). Effect of whey protein concentrate on the survival of Lactobacillus acidophilus in lactose hydrolyzed yogurt during refrigerated storage. Milchwissenschaft, 51(10), 566-569.

Kozioł, J., Gustaw, W., Waśko, A., Skrzypczak, K., Sławińska, A., Sołowiej, B. (2014). Wpływ wybranych preparatów białek mleka na wzrost i przeżywalność Lactobacillus acidophilus oraz właściwości reologiczne mlecznych napojów fermentowanych [Effect of selected milk protein preparations on growth and survival of Lactobacillus casei as well as on rheological properties of fermented milk beverages]. Żywn. Nauka Technol. Jakość, 3(94), 41-55 [in Polish].

Kozioł, J., Skrzypczak, K., Gustaw, W., Waśko, A. (2013). Wpływ preparatów białek mleka na wzrost bakterii $\mathrm{z}$ rodzaju Bifidobacterium [Effect of milk protein preparations on growth of Bifidobacterium]. Żywn. Nauka Technol. Jakość, 3(88), 83-98 [in Polish].

Kuecuekcetin, A. (2008). Effect of heat treatment of skim milk and final fermentation $\mathrm{pH}$ on graininess and roughness of stirred yogurt. Int. J. Dairy Techn., 61(4), 385-390.

Liu, Z., Jiang, Z., Zhou, K., Li, P., Liu, G., Zhang, B. (2007). Screening of bifidobacteria with acquired tolerance to human gastrointestinal tract. Anaerobe, 13, 215-219.

Matijević, B., Božanić, R., Tratnik, L., Jeličić, I. (2008). The influence of whey protein concentrate on growth and survival of probiotic bacteria in whey. Mljekarstvo, 58(3), 243-255.

Puvanenthiran, A., Williams R. P. W., Augustin, M. A. (2002) Structure and visco-elastic properties of set yoghurt with altered casein to whey protein ratios. Int. Dairy J., 12, 383-391.

Saccaro, D. M., Tamime, A. Y., Pilleggi, A., Oliveira, M. N. (2009) The viability of three probiotic organisms grown with yoghurt starter cultures during storage for 21 days at 4 degrees C. Int. J. Dairy Technol., 62, 397-404.

Tamime, A. Y., Robinson, R. K. (2007). Tamime and Robinson's yoghurt: Science and technology. Cambridge: Woodhead. 